\title{
DEMOCRACIA E COMUNICAÇÃO ENTRE GOVERNO E POVO: O PRINCÍPIO DA IMPESSOALIDADE NA PRODUÇÃO DE PROPAGANDA DO GOVERNO
}

\author{
MARCOS ANTÔNIO STRIQUER SOARES ${ }^{1}$ \\ ${ }^{1}$ Doutor em Direito do Estado pela PUC/SP; Professor de Direito Constitucional na graduação, na especialização e no \\ mestrado em Direito Negocial da Universidade Estadual de Londrina; professor de Direito Constitucional na \\ Universidade Norte do Paraná e na Universidade do Oeste Paulista
}

\section{RESUMO}

Oeste trabalho analisa os riscos da propaganda produzida por órgãos governamentais para a democracia. Investiga o totalitarismo para compreender a propaganda produzida nesse tipo de regime político, especialmente no nazismo alemão; investiga, também, a propaganda demagógica e populista; investiga, por fim, o desrespeito ao princípio da impessoalidade, na produção de propaganda dos órgãos públicos, com os vícios da promoção pessoal, do nepotismo e do partidarismo. Considera que a Constituição Federal permite a propaganda dos órgãos públicos e que esta é um instrumento indispensável para a comunicação entre governantes e governados, em um mundo globalizado, de disseminação rápida da informação e com diversidade de fontes. Constata, por fim, que a propaganda dos órgãos públicos deve sofrer controle rigoroso, para se evitar o uso degenerado desse instrumento de persuasão tão poderoso, e para se evitar arbitrariedades dos governantes de plantão e dominação do povo.

Palavras-chave: propaganda do governo; processo de democratização; totalitarismo; direitos fundamentais; princípio da impessoalidade.

\section{DEMOCRACY AND COMUNICATION BETWEEN GOVERNMENT AGENCIES AND PEOPLE: THE PRINCIPLE OF IMPESSOALITY IN THE PRODUCTION OF GOVERNMENT ADVERTISIMENT}

\begin{abstract}
This work examines the dangers of advertisement produced by government agencies to democracy. It investigates the totalitarianism advertisement produced in this type of political regime, especially in Nazi Germany; also, it investigates the populist and demagogic advertisement; it researches, finally, the failure of the disrespect to the impersonality principle in the production of public organisms, with addicts of selfpromotion, nepotism and partisanship. It considers that the Federal Constitution permits advertising of public organisms and that this is an indispensable tool for communication between rulers and ruled, in a globalized world, the rapid dissemination of information and diversity of sources. It notes, finally, that the advertisement of public organisms must undergo to strict control to avoid the degenerate use of this instrument of persuasion so powerful, and to prevent arbitrary decisions by government on duty and domination of the people.
\end{abstract}

Keywords: government advertisement, democratization process, totalitarianism, fundamental rights; impersonality principle. 


\section{INTRODUÇÃO}

No Estado contemporâneo, onde a informação corre em um mundo globalizado quase que em tempo real e o número de fontes de informações é tão elevado que inviabiliza ao cidadão comum a possibilidade de checar sua veracidade, a comunicação entre governo e cidadão é ferramenta de organização da sociedade, surgida de fonte confiável, em princípio, uma vez que participamos dessa organização como titulares do poder do Estado. A Constituição Brasileira, em seu art. $37, \S 1^{\circ}$, permite a propaganda do governo, realizada por órgãos públicos, desde que tenha caráter educativo, informativo ou de orientação social. Caso não persiga uma destas três finalidades, a propaganda deve ser retirada do mundo jurídico.

Este trabalho analisa não exatamente o dispositivo constitucional permissivo da propaganda do governo. Analisa o potencial danoso da propaganda do governo quando foge daqueles objetivos previstos no art. $37, \S 1^{\circ} \mathrm{da}$ Constituição Federal. Estes riscos estão na propaganda de tendência totalitária, na propaganda demagógica, na propaganda populista ou mesmo no desrespeito ao princípio da impessoalidade.

\section{A propaganda de tendência totalitária}

\subsection{O totalitarismo como regime político}

Para iniciar este tópico podemos dizer que a propaganda totalitária é própria de um ambiente político específico, ou seja, ela existe em um modelo de Estado específico, em um regime político específico. A propaganda de tendência totalitária, segundo Domenach (1963, p. 20) "decorre da fusão da ideologia com a política". Antes de estudá-la, é necessário, portanto, entendermos o regime político em que ela está inserida, o totalitarismo.
Como exemplo de Estado totalitário ${ }^{1}$, na história recente, a doutrina cita a Rússia estalinista e a Alemanha nazista.

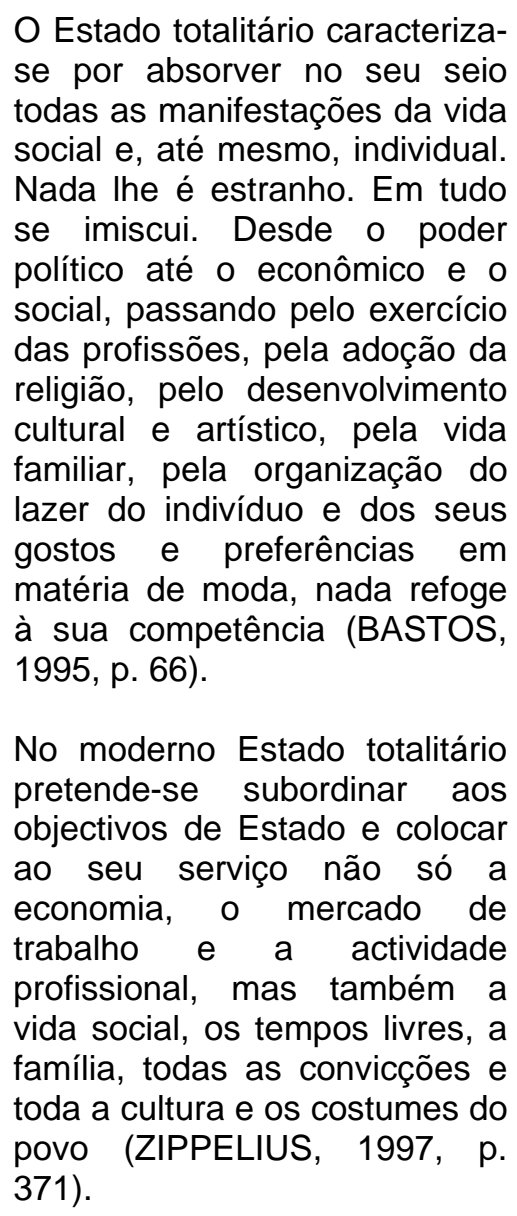

Loewenstein (1970, p. 78), no entanto, adverte: "el concepto 'totalitario' debe ser usado com cuidado. Su validez está limitada a aquellas conformaciones del proceso político en las cuales los detentadores del poder imponen a los destinatarios del poder una determinada ideología."

Temos aí dois elementos: uma imposição unilateral de vontade e uma ideologia, que é imposta. O exame das conseqüências da ideologia é dispensável em nosso estudo, importa, sim, aqui, o exame dos instrumentos de imposição unilateral de vontade, imposição

\footnotetext{
${ }^{1} \mathrm{O}$ totalitarismo não se confunde com o autoritarismo ou com a ditadura. O Estado Autoritário "significa, apenas, que o poder político é exercido por uma minoria contra a vontade da maioria" (BASTOS, 1995, p. 66). A ditadura "tem como elemento característico o fato de estarem unidos na mesma pessoa ou grupo de pessoas os Poderes Executivo e Legislativo, e às vezes também o Poder Judiciário, porém isto raramente" (AZAMBUJA, 2001, p. 224).
} 
unilateral dessa ideologia. Em outra passagem, na mesma página, o autor explica:

[...] el instrumento más importante para imponer la conformidad com los principios ideológicos es el aparato policíaco, omnipresente y omnisciente, que garantiza la seguridad del régimen y acaba com cualquier resistencia potencial. [...] Outro elemento indispensable del ejercicio del dominio es el partido único ${ }^{2}$, que opera no sólo como el voluntario aparato policíaco sobre la base más amplia, sino también como el instrumento que dirigido por el Estado servirá para adoctrinar, coordinar e integrar ideológicamente a la comunidad política.

Tratando das técnicas de dominação, Zippelius (1997, p. 372-373) assevera:

Uma importante preocupação do regime totalitário consiste em infiltrar na burocracia estatal e nas organizações sociais, agentes do poder político para, por esta via, os dirigir e controlar. Para este efeito contribui um partido estatal com organização hierárquica e disciplina rigorosa, que se entranha com as suas secções, em todos os âmbitos importantes da organização do Estado e da vida economica, profissional e cultural. Uma polícia secreta do Estado completa o sistema da

\footnotetext{
${ }^{2}$ Comentando a circunstância de partido único no Estado Afonso Arinos de Melo Franco (1958, p.152-153) traz o seguinte comentário: "A teoria marxista sustenta que, não sendo o partido senão a expressão concreta, no plano político, da luta de classes, a sua diversidade está condicionada à existência de classes sociais. Desde que, com a implantação da ditadura do proletariado, apenas a classe operária tem atuação política, é natural que só goze de reconhecimento legal o partido que a representa. Esta explicação, porém, não satisfaz, ou, pelo menos, não é completa. Com efeito, outros regimes não-marxistas, e até antimarxistas, como, o nazismo e o fascismo, foram levados, invencivelmente, a adotar a prática do partido único, por injunções, não de uma organização social, mas de uma organização estatal. Parece, assim, fora de dúvida, que o problema do partido único está ligado à forma totalitária do Estado, qualquer que seja o seu ideal social. [...] o partido único é menos um instrumento de afirmação de determinada ideologia - como queria Lênine do que a força vital de um certo tipo de Estado, o Estado totalitário, qualquer que seja a ideologia em que o mesmo se baseie". Nas ditaduras - completa o autor - o partido único é um órgão do Estado.
}

penetração organizada do aparelho estatal e da sociedade com funcionários do poder político.

O autor ainda acrescenta os seguintes mecanismos do Estado totalitário: a burocracia é ocupada e vigiada por funcionários do partido e agentes de confiança; dispõe de meios técnicos (os meios de comunicação de massa) para uniformização ideológica; serve-se da repressão de potenciais adversários e da disciplina da comunidade política através do medo e do terror. Para Bastos (1995, p. 67), é possível indicar "constantes em todo o totalitarismo: a existência de dogmas cuja validade ninguém pode pôr em causa; uma idéia messiânica de uma pessoa ou de uma classe social; a identificação do partido dominante com a sociedade e um terror organizado por parte do Estado".

O exercício do poder também ocorre, no totalitarismo, por representantes do povo. A representação popular é, contudo, do tipo simbólica. Explica-nos Gil Kinzo (1980, p. 27):

[...] do mesmo modo que uma bandeira é um símbolo que representa a nação, pode-se pensar num símbolo que represente a totalidade dos cidadãos que compõem uma nação. Representar o povo, no caso de um líder político, nada mais é do que simbolizar uma abstração como a nação; e na medida em que o povo acredita, o líder político o representa por definição. Esta atividade reduz-se a buscar a aceitação dos seguidores através de técnicas de liderança que explorem elementos de crença não racionais ou emotivos. A representação é um meio de assegurar o poder de um líder sobre seus seguidores. O consentimento destes últimos é em boa parte o produto de técnicas de liderança, de paradas e de uniformes. 
Assim, portanto, percebemos que o líder no totalitarismo é o espelho da nação. Antes, porém, a nação é amoldada conforme as pretensões do líder. O líder é o símbolo maior da nação, o qual foi lenta e previamente plantado no imaginário popular.

\subsection{A propaganda totalitária e os riscos da propaganda de tendência totalitária}

A propaganda totalitária é uma espécie de propaganda política, posto que se apresenta como técnica de comunicação persuasiva cujo objeto específico é a propagação e a implantação da ideologia do partido dominante (único dentro do Estado), construindo a uniformização da ideologia na sociedade, realizada na condução dos interesses do partido, ${ }^{3}$ nascida de imposição de vontade das autoridades do partido.

Fiel al principio de un circuito cerrado del poder, los regímenes totalitários monopolizan completamente, y los regímenes autoritarios en el grado más extenso posible,

\footnotetext{
${ }^{3}$ Do livro A Minha Luta, de Adolf Hitler ([1976], p. 428-431), retiramos as seguintes passagens: "A propaganda devia preceder a organização, conquistando o material humano necessário a esta. [...] Cada movimento deve dividir o material humano conquistado para a causa em dois grandes grupos: partidários e militantes. O dever da propaganda é recrutar partidários, o da organização é conquistar militantes. Partidário de um movimento é aquele que aceita a sua finalidade; militante, aquele que luta pela mesma. [...] Deste modo, a constante preocupação da propaganda deve ser no sentido de conquistar adeptos, ao passo que a organização deve cuidar escrupulosamente de seleccionar, entre os partidários, os lutadores mais eficientes. [...] A propaganda trata de impor uma doutrina ao povo inteiro. [...] A propaganda estimula a colectividade no sentido de uma idéia, preparandoa para a vitória da mesma. [...] O primeiro dever da propaganda consiste em conquistar adeptos para a futura organização; o primeiro dever da organização consiste em conquistar adeptos para a continuação da propaganda. $O$ segundo dever da propaganda é a destruição do actual estado de coisas e a disseminação da nova doutrina, enquanto o segundo dever da organização deve ser a luta pelo poder, a fim de fazer triunfar definitivamente a doutrina. [...] Por outras palavras: em cada grande movimento destinado a revolucionar o mundo, a propaganda terá, antes de tudo, de divulgar a idéia do mesmo. Incessantemente terá de esclarecer as massas sobre as novas idéias, atraí-las para as suas fileiras ou, pelo menos, abalar as suas antigas convicções. Como, porém, a divulgação de uma idéia, isto é, a propaganda, deve possuir uma 'coluna vertebral', a doutrina deverá apoiar-se numa sólida organização, a qual deve escolher os seus membros entre os partidários conquistados pela propaganda e crescerá tanto mais rapidamente quanto for mais intensamente promovida. Esta propaganda poderá trabalhar tanto melhor quanto a organização que está por detrás dela for mais forte e mais poderosa".
}

todos los medios de formación de la opinión pública, entre los que se encuentra en primer lugar la radio. Sólo la radio há hecho posible la dictadura en la moderna sociedad de masas. Los destinatarios del poder recibirán propaganda favorable a los detentadores del poder, y serán privados de la información adversa; se les someterá a un eterno lavado de cerebro consistente en una propaganda científica [...]. La voluntad de la comunidad será fabricada. En las sociedades estatales monolíticas, donde se niega el reconocimiento a las fuerzas pluralistas rivalizando entre ellas, el control sobre el aparato de propaganda sólo podrá ser ejercido de forma concentrada por el Estado (LOEWENSTEIN, 1970, p. 418).

Assim, nos regimes totalitários os meios de comunicação servem para formar e conduzir a opinião pública conforme os interesses e a ideologia do grupo dominante.

Ensina Domenach (1963, p. 50-82): “[...] ninguém poderia alimentar a pretensão de encerrar a propaganda dentro de certo número de leis funcionais. Ela é polimorfa e dispõe de recursos quase ilimitados". Apesar disso, o autor apresenta algumas leis observadas na propaganda totalitária: lei da simplificação (tratase de dividir a doutrina e argumentação em alguns pontos, definindo-os o mais claramente possível. O propagandista tem à disposição uma escala inteira de fórmulas: manifestos, profissões de fé, programas, declarações, catecismos, os quais, em geral sob forma afirmativa, enunciam certo número de proposições em texto conciso e claro); lei do inimigo único ${ }^{4}$ (uma boa propaganda

\footnotetext{
4 Em Paula Diehl (1996, p. 86) encontramos a seguinte passagem esclarecedora: "não se deveria 'dispersar o ódio das massas', isto é, deveria-se apontar o mínimo de inimigos possível a serem combatidos e apenas um por vez. Assim, evitar-se-ia que as massas se confundissem. Era preciso que se apresentasse um mundo maniqueísta, de fácil compreensão e de idéias simplistas, pois essa massa deveria ser conquistada por 'seus sentimentos' e não por sua
} 
não visa a mais de um objetivo de cada vez. Trata-se de concentrar o tiro num só alvo durante dado período. Os hitleristas praticaram à perfeição esse método de concentração: aliados aos partidos burgueses e reacionários contra os marxistas, aliados, depois, à direita nacionalista contra os partidos burgueses e, finalmente, ao eliminar os nacionalistas, sempre se arranjaram a fim de terem apenas um inimigo. Os judeus ${ }^{5}$ foram os inimigos mais atacados na Alemanha nazista); lei da ampliação e desfiguração (É a ampliação exagerada das notícias. Coloca em evidência todas as informações favoráveis aos seus objetivos: a frase casual de um político, a passagem de um avião ou de um navio desconhecidos transformam-se em provas ameaçadoras $^{6}$. A hábil utilização de citações destacadas do contexto constitui também processo freqüente); lei de orquestração ${ }^{7}$ (É a

capacidade de análise. Quanto mais simplista e radical a propaganda, mais seguros os resultados obtidos com ela."

Paula Diehl (1996, p. 93) esclarece mais uma vez: "O nacional-socialismo consagrou grande parte de sua propaganda ao anti-semitismo. É por meio da perseguição às minorias e, principalmente, aos judeus, que o sistema se estabiliza. Denominado o inimigo, todos os problemas da sociedade passam a ser atribuídos a ele. A solução parece lógica; ao se exterminar os 'causadores' dos problemas, estes também desaparecerão. $\mathrm{Na}$ interpretação distorcida do nacional-socialismo, os grandes personagens históricos de origem judaica são tidos como responsáveis pela desgraça mundial, seja Karl Marx ou a família Rothschild, passando por Freud e Einstein; não importa o contexto, o fato de ser judeu já é suficiente para ser designado como 'inimigo'. Assim, a minoria judia é responsabilizada pelo 'mal que se abate sobre a Alemanha', servindo de justificativa para o sistema."

6 "A verdade estará numa citação fatual, enquanto a mentira se baseará em generalizações sem fundamento" (RODEE, ANDERSON, CHRISTOL, 1959, p. 163).

7 Do livro de Adolf Hitler ([1976], p. 135-138) retiramos: "A capacidade de compreensão do povo é muito limitada, mas, em compensação, a capacidade de esquecer é enorme. Sendo assim, a propaganda deve-se restringir a poucos pontos. E esses deverão ser valorizados como estribilhos até que o último indivíduo consiga saber exactaente o que representa esse estribilho. Sacrificado esse princípio a favor da variedade, provoca-se uma actividade dispersiva, pois a multidão não consegue nem digerir nem guardar o assunto tratado. [...] Qualquer que seja o talento que se revele na direção de uma propaganda não se conseguirá êxito, se não se levar em consideração sempre e intensamente um postulado fundamental. Ela tem de se contentar com pouco; porém, esse pouco terá de ser repetido constantemente." A propaganda, todavia, foi criada "para convencer as massas. Estas, porém, necessitam - sendo como são de difícil compreensão - de um determinado período de tempo, antes mesmo de estarem dispostas a tomarem conhecimento de um facto, e, só depois de repetidos milhares de vezes os mais simples conceitos, é que a sua memória entrará em funcionamento. Qualquer digressão que se faça nunca deve modificar o sentido do fim visado pela propaganda, que deve infatigável repetição dos temas principais. A repetição pura e simples, entretanto, logo suscitaria o tédio. Ao insistir sobre o tema central deve-se apresentá-lo sob diversos aspectos); lei de transfusão (não se deve contradizer frontalmente uma multidão, mas, de início, declarar-se de acordo com ela, acompanhando-a antes de amoldá-la ao escopo visado. A maior preocupação dos técnicos publicitários reside na identificação e na exploração do gosto popular, mesmo naquilo que tem de mais perturbador $\mathrm{e}$ absurdo, a fim de adaptar-lhe a publicidade e a apresentação de um produto); lei de unanimidade e de contágio ${ }^{8}$ (A pressão do grupo social sobre o individual é fator de conformação da opinião pessoal. Decorre desse fato que inúmeras opiniões não passam, na realidade, duma soma de conformismo, e se mantém apenas por ter o indivíduo a impressão de que a sua opinião é a esposada unanimemente por todos no seu meio. Em conseqüência, será tarefa da propaganda reforçar essa unanimidade e mesmo criá-la artificialmente). Além dessas leis, o autor ainda explica a contrapropaganda, isto é, a propaganda de combate às teses do adversário.

acabar sempre afirmando a mesma coisa. O estribilho pode assim ser iluminado por vários lados, porém o fim de todos os raciocínios deve sempre visar o mesmo estribilho. Só assim a propaganda poderá agir de modo uniforme e decisivo".

Do livro de Adolf Hitler ([1976], p. 352-353) retiramos as seguintes passagens: "Os comícios populares são necessários, justamente porque neles indivíduo que se sente inclinado a tomar parte num movimento mas receia ficar isolado recebe, pela primeira vez, a impressão de uma colectividade maior, o que provoca, na maior parte dos espíritos, um estímulo e um encorajamento. [...] O carácter colectivo nas grandes manifestações não só fortalece o indivíduo, como estabelece a união e concorre para a formação do espírito de classe. [...]. Ao sair da sua pequena oficina ou da sua grande fábrica, onde se sente infinitamente pequeno, e, pela primeira vez, vai a um comício, e aí encontra milhares e milhares de pessoas com as mesmas idéias que a suas; quando é arrastado pela força sugestiva do entusiasmo de três a quatro mil pessoas, quando o êxito visível da causa e a unanimidade de opiniões lhe dão a convicção da justeza do novo movimento e lhe despertam a dúvida sobre a verdade das suas antigas idéias, então estará sob a influência do que poderemos designar por estas palavras - sugestão das massas. A vontade, os anseios, mas também a força de milhares de homens acumulam-se em cada um deles. O indivíduo que foi ao comício vacilando, envolvido em dúvidas, sai dali firmemente fortalecido. Tornou-se membro de uma colectividade." 
Para Ferrés (1998, p. 186 e segs.) os políticos preferem a sedução ao convencimento, a emoção ao discurso, visto que o discurso explícito ativa a consciência do receptor e dispara os seus mecanismos de defesa. ${ }^{9}$ A sedução, pelo contrário, burla os controles da racionalidade. Goebbels, explica Ferrés, pilar da estratégia propagandística nazista, foi paradigma da propaganda oculta, mascarada, do entretenimento transformado em doutrinamento. Preferia influenciar através do entretenimento ao invés da propaganda direta, explícita.

O nazismo pode ser visto como um processo de transferência de poder, durante uma época de frustração devida à crise econômica e social, do povo em direção a uma figura carismática. Produz-se, então, um variado jogo de projeções, associações ou transferências: do povo para o líder, do partido, do Estado e da nação para o líder. As insígnias, os hinos, as grandes manifestações, as liturgias nazistas, tudo age como símbolo aglutinador destes processos de transferência. $^{10}$ Os elementos distintivos, a águia imperial, a suástica ou cruz gamada, a

\footnotetext{
${ }^{9}$ Do livro de Adolf Hitler ([1976], p. 134-135) retiramos as seguintes passagens: "[...] a quem se deve dirigir a propaganda? Aos intelectuais ou às massas menos cultas? A propaganda terá sempre de ser dirigida às massas! Para os intelectuais, ou para aqueles que, hoje, infelizmente assim se consideram, não se deve tratar de propaganda e sim de instrução científica. [...] O objectivo da propaganda não é a educação científica de cada um, mas sim chamar a atenção das massas sobre determinados factos, necessidades, etc., cuja importância só assim cai no círculo visual das referidas massas." A finalidade da propaganda "é a de despertar a atenção das massas e não a de ensinar aos cultos ou àqueles que procuram cultivar o espírito, a sua acção deve ser cada vez mais dirigida para o sentimento e só muito condicionalmente para a chamada razão. [...] Quanto mais modesto for o seu lastro científico e quanto mais ela levar em consideração o sentimento das massas tanto maior será o êxito. [...] A arte da propaganda reside justamente na compreensão da mentalidade e dos sentimentos das grandes massas".

${ }^{10}$ No livro de Adolf Hitler ([1976], p. 349-350) encontramos passagem onde ele examina até mesmo o horário de assembléias nas quais os indivíduos possuem pontos de vista opostos: "A mesma conferência, o mesmo orador, o mesmo tema, produzem efeitos, às dez horas da manhã, diferentes dos que se pode obter às três horas da tarde ou à noite. [...] Pela manhã e mesmo durante o dia, a força de vontade das pessoas parece resistir melhor, com mais energia, contra a tentativa de se lhes impor uma vontade estranha. À noite, deixam-se vencer mais facilmente pela força dominadora de uma vontade forte".
}

bandeira vermelha, os uniformes militares, o gesto fascista, o fogo, os monumentos faraônicos (próprios de todo fascismo), as gigantescas concentrações e manifestações, os símbolos em geral são, ao mesmo tempo causa e efeito, expressão e provocação de sentimentos de identificação.

No totalitarismo a propaganda não serve, apenas, para manter o status estabelecido, mantendo no poder aqueles que lá se encontram e controlam a maquinaria do Estado. Vai além disso criando, produzindo um ambiente propicio.

A propaganda rão
desempenha apenas uma
função estratégica, mas
cumpre também um papel
fundamental na formação e
consolidação do imaginário
nacional-socialista. Por isso,
ela não pode ser vista como
simples instrumento de
conversão política. O mundo
totalitário se constrói em torno
de uma 'realidade' artificial
caracterizada pela manipulação
dos fatos pela abordagem
propagandística.
'realidade' se desmantela
quando confrontada com
elementos fora do seu âmbito,
ou seja, quando percebida
como artificial. A propaganda
tem, então, que proteger as
frágeis estruturas de sua
realidade criada destes
elementos externos que a
ameaçam permanentemente.
Assim, ela funciona como
unidade produtora de sentido,
construindo um imaginário débil
e instável incessantemente
alimentado de novos impulsos
(DIEHL, 1996, p. 83).

Com isto ela mantém o status estabelecido e consolida sua dominação por criar e manter na imaginação do povo a visão de seus desejos.

Por fim, o uso do terror fecha toda e qualquer possibilidade de fuga do sistema 
totalitário. Diehl (1996, p. 97), mais uma vez, tratando da Alemanha nazista, explica:

Uma das principais
características do nacional-
socialismo foi o emprego
sistemático do terror. O terror
tem, nos sistemas totalitários, a
função de preencher as
lacunas deixadas pela falta de
vínculo com a realidade externa
a estes sistemas. Neste ponto
não se pode dissociar a
dualidade terror/propaganda.
Manter o sistema sempre em
movimento, criando fatos e
estados psicológicos que
isolem o mundo totalitário do
mundo externo é uma das
principais funções do terror e
da propaganda. Para que isto
ocorra, o sistema necessita de
indivíduos autômatos que ajam
apenas como peças da
máquina totalitária. Com o
terror, a sociedade é vigiada e
ameaçada, enquanto os
indivíduos vão sendo isolados
uns dos outros até que
alcancem a perfeita solidão.
Por meio do permanente medo
e controle, o terror vai
destruindo os laços que unem
os indivíduos uns aos outros,
eliminando primeiramente as
capacidades políticas e, em
seguida, as sociais. Assim, é
destruída não somente a
liberdade, como a sua própria
fonte. a dociedade
completamente dominada pelo
totalitarismo cai então em um
estado de anomia, perdendo
suas possibilidades criativas e
de interação social.

A propaganda no totalitarismo é, portanto, um instrumento de dominação à disposição dos detentores do poder. Não é o único. Ela é utilizada em conjunto com outros (com o terror, com o partido único, entre outros), possibilitando a dominação total (da sociedade e do Estado). Ela sozinha não seria suficiente para a dominação total. Ela é apenas parte da maquinaria e será conjugada com outros instrumentos, para ser eficiente.
É preciso atribuir o nome de propaganda totalitária a esse tipo de propaganda política e mantê-lo. As gerações futuras devem ter a real dimensão dessa publicidade enganosa na esfera do Estado. Mas não se pode esquecer que tal espécie de propaganda de dominação, do Estado e do povo, somente consegue ser tão eficiente quanto foi recorrendo a outros instrumentos de manutenção da dominação, como o partido único, um conjunto enorme de símbolos (o principal é o próprio líder), o terror, entre outros. Sem envolver outros instrumentos de dominação a propaganda, por si só, não conseguiria ser tão nefasta.

O perigo, no entanto, em uma sociedade de democracia pouco sedimentada, pouco enraizada, é o que podemos chamar de propaganda do tipo totalitária, qual seja, a propaganda que apela para o sentimento do povo e apresenta distorções da realidade (a propaganda contra o inimigo único, ampliação de dados insignificantes e a descaracterização de dados relevantes para a população, em uma propaganda), visando dominar essa sociedade. É curioso observar que a luta do bem contra o mal, a luta do pobre contra o rico, nesse modo simplista, entra no perfil de propaganda de tendência totalitária, na medida em que se eleva um ser como inimigo do povo (o mal, o rico).

Uma sociedade democrática não pode abrir mão de limites para o uso da propaganda política, pois o seu uso degenerado pode acabar com a democracia, o que, levar ao extremo, pode chegar ao totalitarismo. O ápice do Estado totalitário é atingido por um caminho de sedução, de envolvimento do povo por sentimentos e não pela razão. Caso a sociedade tolere "pequenos abusos" no uso desse tipo de publicidade, poderá despertar do pesadelo totalitário sem perceber ter adormecido, como foi para os alemães o fim do nazismo. 


\section{Demagogia e populismo na produção de} propaganda política

Considerando que a expressão propaganda, no Brasil, tem sido acompanhada de um adjetivo para qualificá-la, podemos dizer que demagogia e populismo vêm como adjetivos, especificando os atributos de uma propaganda. Assim, será propaganda demagógica aquela que for realizada com as características da demagogia e será populista aquela que carregar as características do populismo. Devemos, então, entender essas expressões para depois entendermos 0 tipo de propaganda que qualificam.

Podemos entender demagogia como:

[...] Uma praxe política que se apóia na base das massas, secundando e estimulando suas aspirações irracionais e elementares, desviando-a da sua real e consciente participação ativa na vida política. Este processo desenvolve-se mediante fáceis promessas impossíveis de ser mantidas, que tendem a indicar como os interesses corporativos da massa popular ou da parte mais forte e preponderante dela coincidem fora de toda lógica de bom Governo, com os da comunidade nacional, tomada em seu conjunto. Assim, era chamado demagogo [...] na antiga Grécia, aquele que, sendo homem de Estado ou hábil orador, sabia conduzir o povo (BOBBIO, 2000, p. 318).

A propaganda demagógica será, portanto, aquela que intenta conduzir o povo, desviando-o da sua real e consciente participação na vida política, a partir de promessas fáceis, mas que não podem ser mantidas.

Por outro lado, sem entrarmos em discussões detalhadas sobre o tema, podemos dizer que o populismo pode ser entendido como:

[...] denominação atribuída a diversos regimes políticos que surgiram na América Latina depois da crise de 1929, esp. na Argentina, com Juan Domingo Perón, e, no Brasil, com Getúlio Vargas, rompendo com as instituições democráticas, e cujas realizações concretas mais importantes foram: a diminuição do peso relativo das antigas oligarquias, esp. as rurais, a criação de legislação trabalhista que assegurou direitos aos trabalhadores, esp. os urbanos, a rápida industrialização, o nacionalismo como marca da política econômica nacional, o estatismo na economia, o crescimento da classe média. [...] a partir de1980, doutrina e prática política, de esquerda ou de direita, que prega a defesa dos interesses das camadas não privilegiadas da população, mas que freq. se limita a ações de cunho paternalista, angariando dessa forma o apoio popular (HOUAISS; VILLAR, 2001, p. 2261).

Assim, podemos denominar como propaganda populista aquela que prega a defesa dos interesses das camadas não-privilegiadas da população, fazendo uso de ações paternalistas.

\section{O princípio da impessoalidade na produção de propaganda do governo}

O art. 37, § $1^{\circ}$ da Constituição autoriza a propaganda dos órgãos públicos, mas proíbe a utilização de "nomes, símbolos ou imagens que caracterizem promoção pessoal de autoridades ou servidores públicos". Há quem entenda ser este o espírito da norma, proibir o culto ao personalismo (SCHIRMER; GEBRAN NETO, 1991, p. 201). A proibição de promoção pessoal vem no dispositivo, tudo indica, como algo comezinho, uma advertência, para que o administrador não abuse de seu poder. Estancou um problema doméstico, por assim dizer, para indicar que até mesmo estas práticas tão comuns em nossos órgãos públicos não podem ser utilizadas. Muito além da promoção pessoal, a 
proibição assevera apenas a observância do princípio da impessoalidade previsto no caput do art. 37

Rocha (1994, p. 168-169) explica que a promoção pessoal é uma das espécies de vícios de pessoalidade na Administração Pública, um dos mais comuns (ao lado do nepotismo e do partidarismo), agravando o desrespeito ao princípio da impessoalidade. "Estabelece-se, aí, inegável personalismo, do qual decorrem ganhos pessoais diretos ou indiretos, materiais ou profissionais, para o agente". Em outra passagem a autora completa: "Para cumprimento do princípio da impessoalidade é que se requer, constitucionalmente, que a publicidade seja dos comportamentos (atos, programas, obras, serviços e campanhas dos órgãos públicos) administrativos e não dos agentes" (ROCHA, 1994, p. 245).

O princípio da impessoalidade ainda causa divergência entre os estudiosos do Direito Público. De qualquer modo, "a impessoalidade caracteriza-se, pois, na atividade administrativa, pela valoração objetiva dos interesses públicos e privados envolvidos na relação jurídica a se formar, independentemente de qualquer interesse político" (FIGUEIREDO, 2004, p. 63). Para alguns, ele é o princípio da igualdade transplantado para o campo da Administração Pública, impondo que a atividade administrativa não faça acepção de pessoas (MELLLO, 2001, p. 84; GASPARINI, 2001, p. 8; FERREIRA FILHO, 1997, p. 238 - para este autor, a igualdade é apenas um dos prismas sob o quais é possível observar o princípio da impessoalidade). Para outros, a impessoalidade é o clássico princípio da finalidade, a partir do qual a Administração não pode atuar com vistas a prejudicar ou beneficiar pessoas determinadas, uma vez que é sempre o interesse público que tem que nortear o seu comportamento (MEIRELLES, 2004, p. 91; DI PIETRO, 2004, p. 71 - para esta autora, a finalidade pública é apenas um dos sentidos sob o quais é possível observar o princípio da impessoalidade).

Também é possível encontrar o princípio da impessoalidade com o significado de imparcialidade, $^{11}$ qualidade de ser imparcial (FIGUEIREDO, 2004, p. 64). Tal entendimento, contudo, pode gerar controvérsias com o campo de ação do Poder Judiciário ${ }^{12}$. A imparcialidade exigida do administrador público não tem a mesma dimensão da exigida de um juiz de direito. O primeiro executa a lei no interesse da Administração, o que sugere, em alguns casos, uma decisão parcial, em favor da Administração, sempre em busca do interesse público. Embora o administrador tenha o dever de imparcialidade, isto não é exigido da Administração Pública, do Estado enquanto pessoa jurídica. O juiz, além de executar a lei para a solução de conflito, do qual não participa, recebe proteção da Constituição (o art. 95 traz garantias e vedações) para 0 desempenho imparcial da função jurisdicional. Aqui, tanto o juiz como o Estado-juiz têm o dever de imparcialidade ${ }^{13}$.

O princípio da impessoalidade encontra, ainda, outra explicação:

\footnotetext{
${ }^{11}$ Merece destaque a anotação de Canotilho (1993, p. 172) para quem o princípio da imparcialidade da administração existente na Constituição portuguesa (art. 266): "é um princípio simultaneamente negativo e positivo: ao exigir-se imparcialidade proíbe-se o tratamento arbitrário e desigual dos cidadãos por parte dos agentes administrativos, mas, ao mesmo tempo, impõe-se a igualdade de tratamento dos direitos e interesses dos cidadãos através de um critério uniforme da ponderação dos interesses públicos".

12 "O caráter de imparcialidade é inseparável do órgão da jurisdição. O juiz coloca-se entre as partes e acima delas [...] para assegurar a imparcialidade do juiz, as constituições Ihe estipulam garantias (Const., art. 95), prescrevem-lhe vedações (art. 05, par.ún.) e proíbem juízos e tribunais de exceção (art. 50, inc. XXXVII)" (CINTRA; GRINOVER; DINAMARCO, 2004, p. 51-52).

${ }^{13}$ Conforme Chiovenda (2000, p. 17-18), administrar é uma atividade por si mesma imposta direta e imediatamente pela lei a órgão público; a Administração Pública age por conta própria, não em lugar de outrem. O juiz age atuando a lei, a administração age em conformidade com a lei. O juiz considera a lei em si mesma, o administrador considera-a como norma de sua própria conduta. A administração é uma atividade primária, a jurisdição é uma atividade secundária. A própria administração julga, pois que não se age a não ser com apoio num juízo, mas julga sobre a própria atividade. Ao contrário, a jurisdição julga da atividade alheia e duma vontade de lei concernente a outrem.
} 
[...] significa que os atos $e$ provimentos administrativos são imputáveis não ao funcionário que os pratica, mas ao órgão ou entidade administrativa em nome do qual age o funcionário. Este é um mero agente da Administração Pública, de sorte que não é ele o autor institucional do ato. Ele é apenas o órgão que formalmente manifesta a vontade estatal (SILVA, 2000, p. 647).

Esta explicação não é simplista, pelo contrário, estamos diante de um dos pontos cruciais de toda a Teoria do Estado: o problema da vontade da pessoa jurídica Estado, o problema do querer do Estado; o problema da relação que se estabelece entre o povo $e$ as pessoas encarregadas de querer por ele.

Essa problemática encontra resposta em Malberg (2001, p. 1006-1009), para quem a palavra órgão expressa duas idéias principais. Significa, em primeiro lugar,

\begin{abstract}
"[...]que el individuo que desempeña la función de órgano opera [...] como un instrumento del que se vale el ser colectivo para el ejercicio de poderes que sólo a él le pertenecen. [...] Así pues, la teoría del órgano tiene por objeto, en primer lugar, señalar que, si bien de hecho la voluntad estatal reside y tiene su origen en los hombres encargados por la Constitución de querer por el Estado o por la nación, el poder que ejercen estos individuos no es en ellos una potestad originaria, un derecho propio, sino una simples competencia estatal, es decir, una potestad que se ejerce por cuenta exclusiva del Estado".
\end{abstract}

Nas páginas seguintes, o autor continua (MALBERG, 2001, p. 1012-1013):

"La palabra órgano tiene por objeto, en segundo lugar, señalar que el órgano no se identifica com las personas físicas que desempeñan la funcion orgánica. [...] la palabra órgano hace abstracción de los individuos encargados de querer por el Estado. Es un término impersonal, que únicamente se refiere a la organización estatal y que relega al último plano a los individuos, cuyo concurso es indispensable sin embargo para el funcionamiento de esta organización. Indudablemente, el valor y las actitudes personales de los hombres que sirven de órganos al Estado tienen para éste gran importancia desde el punto de vista político; pero desde el punto de vista jurídico, la consideración de su individualidad es indiferente".

Mesmo essas atitudes políticas dos homens que servem os órgãos do Estado conhecem limites: essa liberdade esbarra no interesse público ${ }^{14}$ e em balizas legais tracejadoras do poder discricionário.

A impessoalidade pressupõe, portanto, que os atos e provimentos administrativos são imputáveis não ao funcionário que os pratica, mas ao órgão da Administração em nome do qual age o funcionário. O órgão opera como um instrumento de que se vale o povo para o exercício de seu poder e também assinala que o órgão não se identifica com as pessoas físicas que desempenham as funções estatais. É certo que a Constituição deixa uma margem discricionária às autoridades públicas (titulares dos órgãos públicos), mas mesmo dentro dessa

\footnotetext{
${ }^{14}$ Explica-nos Carré de Malberg (2001, p. 41-42): "Sólo los hombres, en efecto, pueden ser sujetos de intereses, y por lo tanto es imposible concebir que el Estado tenga intereses suyos que no sean intereses humanos.[...] desde el punto de vista jurídico, se puede hablar de bienes del Estado o también de intereses del Estado; pero desde el punto de vista de la realidad, el pretendido interés colectivo del Estado se resuelve invariablemente en intereses individuales, y ello no solamente en el sentido de que, de hecho, los individuos son los que se benefician de las medidas tomadas por el Estado en vista del interés nacional, sino también por el motivo de que la actividad estatal, cuando se ejerce por cuenta del grupo nacional, no puede tener otro fin, realmente, que dar satisfacción a los intereses de sus miembros presentes y futuros, que pasan a ser así los verdaderos destinatarios de las medidas de interés nacional".
} 
liberdade deve prevalecer o interesse público, de modo impessoal. A afronta ao princípio da impessoalidade não surge apenas com o mau uso da regra de competência, mas é o uso desta em proveito pessoal. Mesmo um ato praticado dentro do poder discricionário deve ser impessoal e ser condutor do interesse público. Se um ato é formalmente correto, desde seu motivo até sua finalidade, mas encontram-se provas de interesse pessoal em sua prática (por exemplo, provas de que uma desapropriação teve como intenção a vingança de inimigo político), ele será nulo por ferir o princípio da impessoalidade.

Não importa que o ato tenha cumprido uma finalidade pública, não importa que a lei contenha autorização para sua prática, importa sim que a atitude política, o ambiente político que provocou sua prática não foi impessoal, daí não ter atingido o interesse público. Não importa que o novo ato repita o conteúdo daquele retirado do mundo jurídico por vício de impessoalidade, é até bem possível que isto aconteça, mesmo que praticado por outra autoridade. Importa, sim, que a atitude da autoridade não tenha causa em interesses pessoais, que o ambiente político em que o ato é gerado não deturpe o interesse público. Havendo provas do vício, não importa que ele seja formalmente legítimo, ele deve ser retirado do mundo jurídico para que um novo ato seja praticado, oxalá desta vez portador do interesse público.

Rocha destaca três dos vícios mais comuns de pessoalidade na Administração Pública: o nepotismo (1994, p. 158), pelo qual os agentes públicos, valendo-se dos cargos por eles ocupados, concedem favores e benéficos pessoais a seus parentes e amigos; o partidarismo (1994, p. 164), pelo qual as decisões administrativas passam a ser tomadas não mais de acordo com o interesse público, para o bem de toda a sociedade, mas segundo as conveniências da facção que está no Poder ou de seus "correligionários" e as pessoas que compõem "os quadros partidários" (o objetivo é, então, basicamente, permanecer no Poder e tutelar os interesses de grupos e facções políticas); e a promoção pessoal (1994, p. 168), pela qual o administrador, valendo-se do cargo público por ele ocupado, e precisando ter as atividades a ele inerentes divulgadas para conhecimento da população, busca contornar o impedimento constitucional de personalizar o exercício da função pública e tirar proveitos daquela difusão dos fatos, atos e serviços.

\section{Os riscos da propaganda do governo para a democracia}

O tema "propaganda do Estado", na democracia, não tem sido abordado adequadamente. O uso da propaganda pelo Estado na moderna sociedade de massas é inevitável. Isto por que, numa sociedade de massas, o governo necessita de instrumentos de comunicação de massa. Além disso, no Estado contemporâneo, a informação corre um mudo globalizado quase que em tempo real e o número de fontes de informações é tão elevado que inviabiliza ao cidadão comum a possibilidade de checar a veracidade da informação. Cabe ao governo a condução do interesse público e o uso dessa ferramenta denominada propaganda para persuadir a população a condutas de interesse público, como campanha de vacinação, entre outros exemplos.

A questão, desse modo, não é como acabar com a propaganda do governo, mas como exercer controle eficiente sobre esse potencial que pode ser usado em benefício de grupos e em detrimento da sociedade. Desse modo, o Estado democrático precisa encontrar meios para evitar que o uso da propaganda pelos detentores do poder seja desviado para o interesse pessoal ou de um grupo. Nosso problema, portanto, não é 
proibir a propaganda pelo Estado. O problema é o controle que deve ser feito quando de seu uso.

A democracia depende de aprendizado do povo. Aprender o quê dá certo ou errado; aprender que uma promessa foi só uma promessa que desde o seu início já não poderia ter sido cumprida; aprender que não existe milagre algum (milagre do crescimento, por exemplo) e que tudo depende de muito esforço de todos. Esse aprendizado de democracia é um processo lento. Enquanto esse aprendizado não estiver bem sedimentado, bem enraizado, os riscos de embarcarmos nas promessas de governantes astutos são enormes. Está justamente aí o risco das propagandas demagógica, populista, de tendência totalitária, as quais de um modo geral estarão recheadas do vício personalista.

O objetivo deste artigo não é apresentar os mecanismos de controle da propaganda do governo. O objetivo é advertir para os riscos desse tipo de propaganda voltada para a dominação. O risco da dominação, mesmo que parcial (para levar "apenas" parte dos bens e interesses do Estado), mas mesmo assim, o risco de abusos da máquina em favor de interesses que não são públicos e que podem ser evitados por instrumentos adequados de controle. Estes instrumentos de controle, contudo, cabem como objeto de estudo de outro artigo.

\section{REFERÊNCIAS}

AZAMBUJA, D. Introdução à ciência política. 14.ed. São Paulo: Globo, 2001.

BASTOS, C. R. Curso de teoria do Estado e ciência política. 3.ed. São Paulo: Saraiva, 1995.

BOBBIO, N. Dicionário de política. 5.ed. Brasília: Ed. UNB, 2000.

CANOTILHO, J. J. G. Direito constitucional. 6.ed. Coimbra: Almedina, 1993.
CHIOVENDA, G. Instituições de direito processual civil. 2.ed. Campinas: Bookseller, 2000. v. 2 .

CINTRA, A. C. de A.; GRINOVER, A. P.; DINAMARCO, C. R. Teoria geral do processo. 20.ed. São Paulo: Malheiros, 2004.

DI PIETRO, M. S. Z. Direito administrativo. 17.ed. São Paulo: Atlas, 2004.

DIEHL, P. Propaganda e persuasão na Alemanha nazista. São Paulo: Annablume, 1996.

DOMENACH, J.-M. A propaganda política. 2.ed. São Paulo: Difusão Européia do Livro, 1963.

FERREIRA FILHO, M. G. Comentários à constituição brasileira de 1988. São Paulo: Saraiva, 1997. v.1.

FERRÉS, J. Televisão subliminar: socializando através de comunicações despercebidas.

Tradução por Ernani Rosa e Beatriz A. Neves. Porto Alegre: Artmed, 1998.

FIGUEIREDO, L. V. Curso de direito administrativo. 7.ed. São Paulo: Malheiros, 2004.

FRANCO, A. A. de M. Curso de direito constitucional. Rio de Janeiro: Forense, 1958. v.1.

GASPARINI, D. Direito administrativo. 6.ed. São Paulo: Saraiva, 2001.

GIL KINZO, M. D. Representação política e sistema eleitoral no Brasil. São Paulo: Edições Símbolo, 1980.

HITLER, A. A minha luta. Tradução por Jaime de Carvalho e Fernando Ribeiro de Melo. Lisboa: Edições Afrodite, [1976].

HOUAISS, A.; VILLAR, M. de S. Dicionário Houaiss da Língua Portuguesa. Rio de Janeiro: Objetiva, 2001.

LOEWENSTEIN, K. Teoría de la constitución. 2.ed. Barcelona: Ediciones Ariel, 1970.

MALBERG, R. C. de. Teoría general del estado. 2.ed. México: Fondo de Cultura Económica, 2001.

MEIRELLES, H. L. Direito administrativo brasileiro. 29.ed. São Paulo: Malheiros, 2004. 
MELLO, C. A. B. de. Curso de direito

administrativo. 13.ed. São Paulo: Malheiros, 2001.

ROCHA, C. L. A. Princípios constitucionais da administração pública. Belo Horizonte: Del

Rey, 1994.

RODEE, C. C.; ANDERSON, T. J.; CHRISTOL, C. Q. Introdução à ciência política. Tradução por Marina Teles de Menezes. Rio de Janeiro: Agir, 1959. t.2.

SCHIRMER, M. S. de A.; GEBRAN NETO, J. P. Publicidade estatal da Constituição Federal de 1988. Revista de Direito Público, São Paulo, v. 24, n. 97, p. 201-205, 1991.

SILVA, J. A. da. Curso de direito constitucional positivo. 17.ed. São Paulo: Malheiros, 2000.

ZIPPELIUS, R. Teoria geral do estado. Lisboa: Fundação Calouste Gulbenkian, 1997. 